\title{
Pencarian Rute Optimal Dengan Metode Steepest Ascent Hill Climbing Untuk Tempat Wisata Di Bandung Menggunakan Android
}

\author{
Youllia Indrawaty Nurhasanah ${ }^{1 *}$, Sofia Umaroh ${ }^{2}$, Ninda Halimah AI Ghoniyyah ${ }^{3}$ \\ 1,3Program Studi Informatika, Institut Teknologi Nasional \\ 2Program Studi Sistem Informasi, Institut Teknologi Nasional \\ 1youllia@itenas.ac.id
}

\begin{abstract}
Abstrak
Minimnya informasi jalur menuju tempat wisata membuat wisatawan bingung dalam memilih jalur terpendek. Untuk mengatasi hal tersebut, penelitian ini mengusulkan sebuah sistem pencarian rute optimal dengan metode steepest ascent hill climbing untuk mencari rute paling optimal ke tempat wisata. Proses pencarian tempat wisata ini diawali dengan mencari jarak latitude dan longitude dari setiap tempat wisata beserta jarak antar tempat wisata menggunakan google maps, lalu jarak tersebut dimasukkan ke metode steepest ascent hill climbing dengan tahapan awal menentukan jumlah kombinasi, dimana dari kombinasi tersebut menghasilkan jumlah lintasan turunan. Kemudian menukar lintasan awal dengan lintasan turunan tersebut dengan menggunakan teori graf. proses ini terus berulang hingga jika lintasan awal lebih kecil daripada lintasan turunan maka lintasan tersebut yang dijadikan lintasan efektif dan rute akan ditampilkan di google maps. Maka berdasarkan pengujian sistem yang dilakukan, metode steepest ascent hill climbing yang digunakan sebagai metode utama penelitian ini dapat diimplementasikan pada pencarian rute terefektif atau tercepat dengan menggunakan metode graph tidak berarah untuk proses penukaran antar tempat wisata.
\end{abstract}

Kata kunci: Rute Optimal, SAHC, Graf, Android.

\begin{abstract}
The lack of information on the path to tourist attractions makes tourists confused in choosing the shortest path. To overcome this, this study proposes an optimal route search system with the steepest ascent hill climbing method to find the most optimal route to tourist attractions. The search process for this tourist spot begins by looking for the latitude and longitude distance of each tourist spot along with the distance between tourist attractions using google maps, then the distance is entered into the steepest ascent hill climbing method with the initial stage of determining the number of combinations, where the combination results in the number of derivative trails. Then swap the initial path with the derivative path using graph theory. This process is repeated so that if the initial trajectory is smaller than the descended path, the effective route and route will be displayed on google maps. So based on the system testing conducted, the steepest ascent hill climbing method used as the main method of this research can be implemented in the search for the most effective or fastest route using the undirected graph method for the exchange process between tourist attractions.
\end{abstract}

Keyword: Optimal Route, SAHC, Graph, Android

\section{PENDAHULUAN}

Meningkatnya sektor pariwisata di Indonesia menjadikan para wisatawan memiliki banyak pilihan tempat wisata untuk dikunjungi. Namun, keberagaman tempat wisata tidak jarang membuat wisatawan mengalami kesulitan untuk menentukan lokasi wisata yang ingin dikunjungi dikarenakan keterbatasan waktu yang dimiliki [1]. Hal ini dikarenakan minimnya informasi mengenai jalur optimal antar tempat wisata 
menyebabkan wisatawan kebingungan dalam memilih jalur optimal [2]. Minimnya informasi mengenai jalur optimal beserta tidak tersedianya rute untuk touring ke tempat wisata tersebut tidak ditangani oleh aplikasi Google Maps yang ada saat ini. Hal ini menjadi masalah bagi para wisatawan yang akan berkunjug ke berbagai tempat wisata dalam 1 waktu.

Dari permasalahan tersebut dapat diselesaikan dengan penelitian menggunakan metode yang telah dilakukan pada penelitian sebelumnya seperti Algoritma Dijkstra, metode simple hill climbing dan metode steepest ascent hill climbing yaitu tentang pencarian rute optimal. Menurut [3] waktu proses algoritma Dijkstra adalah 0,1113 ms sedangkan waktu proses metode Steepest Ascent Hill Climbing adalah 0,0114 ms. Hal ini menunjukkan bahwa metode Steepest Ascent Hill Climbing memiliki waktu proses yang lebih cepat dari pada algoritma Dijkstra karena Steepest Ascent Hill Climbing hanya memilih titik lokasi berdasarkan nilai heuristik terbaik sementara Dijkstra tidak, melainkan mengunjungi setiap titik lokasi terlebih dahulu baru kemudian menemukan solusi. Dan pada pencarian dengan menggunakan metode Simple Hill Climbing menurut [4] prosesnya membutuhkan waktu yang relatif lama karena harus menghitung kemungkinan banyak lintasan dan keputusan yang telah diambil pada suatu langkah tidak dapat diubah lagi pada langkah selanjutnya. Sedangkan pada metode steepest ascent hill climbing tidak memerlukan waktu yang lama karena langsung melihat nilai heuristiknya.

Metode steepest ascent hill climbing merupakan metode algoritma yang banyak digunakan untuk permasalahan optimasi. Salah satu penerapannya adalah untuk mencari rute yang terpendek dengan cara memaksimumkan atau meminimumkan nilai dari fungsi optimasi yang ada. Fungsi optimasi yang dimaksud yaitu penggantian titik pengguna, sehingga mempengaruhi rute terpendek yang dicari. Menurut [5] metode steepest ascent hill climbing dapat memberikan rute menuju fasilitas pelayanan darurat di kota Bogor. Metode steepest ascent hill climbing digunakan pada penelitian ini untuk penyelesaian masalah rute optimal antar tempat wisata di kota Bandung dengan memperhatikan aspek jarak yang optimal.

Berdasarkan pemaparan tersebut, bahwa pencarian rute optimal untuk wisatawan sangat diperlukan, dikarenakan setiap wisatawan memiliki waktu yang sangat terbatas pada kunjungan tersebut. Pada penelitian ini metode steepest ascent hill climbing digunakan sebagai pencarian rute optimal untuk mencari tempat wisata di Bandung. 


\section{Tinjauan Pustaka}

\subsection{Penelitian Terkait}

- Penelitian yang berjudul Optimasi Rute Lokasi Wisata Kota Malang Menggunakan Metode Algoritma Genetika. Penelitian ini dilakukan untuk implementasi pencarian lokasi wisata di Kota Malang dengan Algoritma Genetika[2].

- Penelitian yang berjudul Penerapan Metode Steepest Ascent Hill Climbing Pada Model Pencarian Rute Terdekat Fasilitas Pelayanan Darurat Di Kota Bogor Berbasis Android. Penelitian ini dilakukan untuk pencarian rute tercepat dengan metode Steepest Ascent Hill Climbing dengan berdasrkan titik instansi pemadam, polisi dan rumah sakit yang ada di Kota Bogor [5].

- Penelitian yang berjudul Penerapan Metode Simple Hill Climbing Search Untuk Pencarian Lokasi Terdekat Sekolah Menengah Atas Muhammadiyah. Penelitian ini dilakukan untuk pencarian lokasi terdekat untuk SMA Muhammadiyah yang berada di sekitar pengguna [6].

- Penelitian yang berjudul Penerapan Metode Steepest Ascent Hill Climb Pada Permainan Puzzle. Penelitian ini dilakukan untuk implementasi metode Steepest Ascent Hill Climbing pada permainan puzzle yang berfungsi mempertimbangkan langkah selanjutnya berdasarkan nilai heuristik [7].
- Penelitian yang berjudul Penerapan Metode Hill Climbing Pada Sistem Informasi Geografis Untuk Mencari Lintasan Terpendek. Penelitian ini dilakukan untuk implementasi metode hill climbing pada sistem informasi berbasis geografis yang menghasilkan jalur terpendek [8].

- Penelitian yang berjudul Aplikasi Pencarian Rute Terdekat Lokasi Klinik Kesehatan Menggunakan Algoritma Steepest Ascent Hill Climbing. Penelitian ini dilakukan untuk pencarian rute terbaik menuju klinik kesehatan yang ada di Lhokseumawe berdasarkan rute terpendek menggunakan metode Steepest Ascent Hill Climbing [9].

- Penelitian yang berjudul Representasi Matriks untuk Proses Crossover Pada Algoritma Genetika untuk Optimasi Travelling Salesman Problem. Penelitian ini dilakukan untuk mendapatkan jalur paling optimum pada kasus travelling salesman problem menggunakan metode genetika [10].

- Penelitian yang berjudul Perbandingan Algoritma Hill Climbing Dan Algoritma Ant Colony Dalam Penentuan Rute Optimum. Penelitian ini meneliti perbandingan antara Algoritma Hill Climbing dengan Algoritma Ant Colony dalam mencari yang paling optimum pada studi kasus pelayaran kapal feri di daerah Ambon [11]. 
- Penelitian yang berjudul Penyelesaian

Travelling Salesman Problem (TSP) Menggunakan Algoritma Hill Climbing dan MATLAB. Penelitian ini dilakukan untuk menuntaskan permasalahan TSP dengan metode hill climbing menggunakan platform matlab pada implementasi [12].

- Penelitian yang berjudul Pembuatan Game Slider Puzzle Menggunakan Metode Steepest Ascent Hill Climbing Berbasis Android. Penelitian ini dilakukan untuk membuat game puzzle dengan memanfaatkan metode steepest ascent hill climbing pada platform android [13].

\subsection{Landasan Teori}

Pada pembangunan sistem menggunakan berbagai teori penunjang antara lain:

\section{Graf}

Sebuah graf $\mathrm{G}$ berisikan dua himpunan yaitu himpunan berhingga tak kosong $V(G)$ dari objekobjek yang disebut titik dan himpunan berhingga (mungkin kosong) yang elemen-elemennya disebut sisi sedemikian hingga setiap elemen e dalam $\mathrm{E}(\mathrm{G})$ merupakan pasangan tak berurutan dari titik-titik $V(G)$.

Rumus Graf yaitu:

$$
\mathrm{G}=(\mathrm{V}, \mathrm{E})
$$

Dengan Keterangan berada pada Gambar 1.

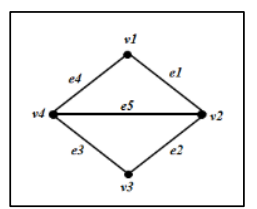

Gambar 1. Sebuah graf

Pada Gambar 1., v1, v2, v3, v4 adalah simpul, sedangkan $e 1, e 2, e 3, e 4$ adalah sisi.

Graf dikelompokkan menjadi beberapa jenis bergantung pada sudut pandang pengelompokkannya. Berdasarkan sisi ganda dikelompokkan menjadi 2 jenis yaitu graf sederhana dan graf tak sederhana, yang umumnya bersisi ganda. Kemudian berdasarkan orientasi arah pada sisi dikelompokkan menjadi 2 yaitu graf yang sisinya tidak berarah dan graf yang sisinya berarah. Lalu berdasarkan jumlah simpul dibagi menjadi 2 jenis yaitu graf berhingga dan tak berhingga. [14]. Pada terminologi graf terdapat graf berbobot yaitu graf yang setiap sisinya diberi sebuah harga (bobot).

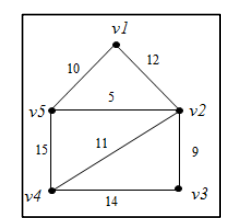

Gambar 2. Graf Berbobot

Model jenis graf yang digunakan pada penelitian dengan metode steepest ascent hill climbing ini adalah graf tidak terarah dan berbobot. Yang artinya graf yang sisinya tidak mempunyai arah. Dan urutan pasangan simpul yang dihubungkan oleh sisi tidak diperhatikan.

Teori graf ini dimasukkan kedalam rumus kombinasi pertukaran antar tempat wisata, untuk 
menentukan berapa banyak jumlah kombinasi penukaran tempat wisata tersebut dan menghasilkan proses pencarian rute dengan jarak terpendek.

\section{Metode Steepest Ascent Hill Climbing}

Metode Steepest Ascent Hill Climbing merupakan metode algoritma yang banyak digunakan untuk permasalahan optimasi. Salah satu penerapannya adalah mencari rute yang terpendek dengan cara memaksimumkan atau meminimumkan nilai dari fungsi optimasi yang ada. Fungsi optimasi yang dimaksud yaitu penggantian titik tujuan dan titik pengguna, sehingga mempengaruhi rute terpendek yang dicari. Secara harfiah steepest berarti paling tinggi, sedangkan ascent berarti kenaikan. Dengan demikian steepest ascent berarti kenaikan paling tinggi. Jadi prinsip dasar dari metode ini adalah mencari kenaikan paling tinggi dari keadaan sekitar untuk mencapai nilai yang paling optimal [5]. Hal ini yang menyebabkan metode ini memiliki tingkat optimalisasi pencarian rute yang lebih baik dari Simple Hill Climbing.

Contoh Kasus:

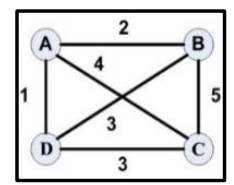

Gambar 3. Simulasi Cara Kerja Metode Steepest Ascent Hill Climbing

Terdapat beberapa tahapan dalam proses metode steepest ascent hill climbing yaitu:
1. Rumus mencari Steepest Ascent Hill Climbing:

$\mathrm{K}=\frac{n !}{2 !(n-2) !}$

Keterangan:

$\mathrm{K}$ : Kombinasi

n: Jumlah Titik Tujuan

2: Menukar posisi urutan antara 2 titik tujuan dalam suatu lintasan

$$
\begin{aligned}
\mathrm{K} & =\frac{n !}{2 !(n-2) !}=\frac{4 !}{2 !(4-2) !}=\frac{4 \cdot 3 \cdot 2 \cdot 1}{2 \cdot 1(2) !}=\frac{4 \cdot 3}{2 \cdot 1}=\frac{12}{2} \\
& =6 \text { Kombinasi }
\end{aligned}
$$

2. Pola kombinasi tukar antar titik tujuan:

Pada pola kombinasi tukar antar titik tujuan ini, menggunakan teori graf. Dengan model jenis graf tidak terarah dan berbobot. Yang artinya graf yang sisinya tidak mempunyai arah. Dan urutan pasangan simpul yang dihubungkan oleh sisi tidak diperhatikan.

Rumus Graf yaitu: $G=(V, E)$

Keterangan:
G: Graf
V: Simpul
E: Sisi

Pada Gambar 3. untuk V yaitu $(A, B, C, D)$, dan untuk $E$ yaitu $(2,5,3,1,3,4)$.

Pola kombinasi tukar tempat wisata:

1. $(1,2)$ : Menukar posisi kota kesatu dengan kota kedua.

2. (1,3): Menukar posisi kota kesatu dengan kota ketiga.

3. (1,4): Menukar posisi kota kesatu dengan kota keempat. 
4. (2,3): Menukar posisi kota kedua dengan kota ketiga.

5. $(2,4)$ : Menukar posisi kota kedua dengan kota keempat.

6. (3,4): Menukar posisi kota ketiga dengan kota keempat.

\section{Pencarian}

Keadaan awal berada di ABCD dengan jarak 10 KM. Berdasarkan pada Gambar .4., keadaan awal lintasan yaitu $A B C D(=10)$.

1. Pada level satu, yang memiliki nilai heuristik yang lebih baik dari lintasan $A B C D$ yang panjangnya 10 adalah lintasan CBAD dan ABDC dengan lintasan sama dengan 8. Karena ada dua node yang nilainya sama dan lebih baik dibandingkan dengan node tetangganya yang lain maka kita dapat memilih salah satu node yang ingin dibuka untuk melanjutkan pencarian solusi selanjutnya. Maka dipilinnya node CBAD untuk pencarian selanjutnya.

2. Pada level dua, diperoleh lintasan CDAB dengan panjang lintasan adalah 6 sebagai lintasan yang lebih baik nilai heuristiknya dibandingkan node lintasan sebelumnya dan juga dibandingkan dengan node-node tetangganya.

3. Pada level tiga, tidak ditemukan nilai heuristic yang lebih baik dibandingkan lintasan $C D A B$ sehingga pencarian berhenti dan solusi yang diperoleh untuk lintasan terpendek adalah CDAB dengan panjang lintasan adalah 6 .

(Pada level tiga, nilainya tidak ada yang lebih kecil dari yang sebelumnya, maka nilai terkecil itu adalah GOAL).

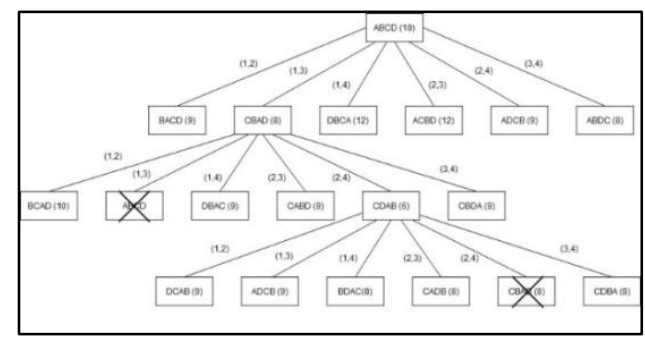

Gambar 4. Simulasi Metode steepest ascent hill climbing

\section{Metode Penelitian}

Pada tahap awal, pengguna memilih lintasan awal tempat wisata untuk dijadikan lintasan awal yang sudah terdaftar dalam daftar tempat wisata. Kemudian sistem akan menunjukkan urutan efektif menuju tempat wisata yang sudah dihitung berdasarkan metode steepest ascent hill climbing. Proses pencarian rute menggunakan nilai latitude dan longitude yang saling berhubungan antara setiap tempat wisata. Proses akan diulangi secara terus-menerus dengan kondisi ditukar setiap tempat wisata berdasarkan nilai latitude dan longitude terpendek. Kemudian proses akan berhenti saat current state memiliki nilai yang sama dengan goal state. Berdasarkan sistem maka dibuat rute selanjutnya yang akan menghasilkan rute optimal berdasarkan jarak terpendek antar 
tempat wisata sesuai dengan metode steepest ascent hill climbing.

\section{Rancangan Umum}

Pada proses perancangan sistem ditunjukan pada Gambar 5. Berdasarkan Gambar 5., dijelaskan bahwa alur kerja sistem dimulai dari tahapan ke 1 mengolah lokasi tempat wisata dengan metode Steepest Ascent Hill Climbing dengan bantuan Google Maps untuk mendapatkan jarak setiap tempat wisata pada tahap ke 2 , setelah di proses rute akan ditampilkan dengan menggunakan Google Maps API Direction pada maps.

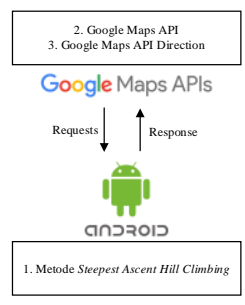

Gambar 5. Perancangan Kerja Sistem

\section{Blok Diagram}

Blok diagram dari rancangan sistem yang dibangun akan digambarkan oleh Gambar 6 .

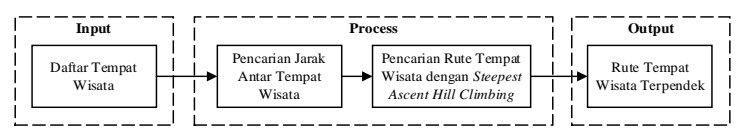

Gambar 6. Blok Diagram Sistem

Berdasarkan Gambar 6, terdapat beberapa point yang akan dijelaskan dalam pointer dibawah ini:

1. Input berupa daftar tempat wisata pada aplikasi yang dirancang, tempat wisata ini yang akan digunakan untuk proses pencarian rute terpendek.

2. Process terdiri dari pencarian jarak antar tempat wisata dan pencarian rute tempat wisata dengan menggunakan metode steepest ascent hill climbing.

Output terdiri dari srute tempat wisata dengan jarak terpendek.

\section{Studi Kasus}

Simulasi data dan perhitungan metode steepest ascent hill climbing. Terdapat 4 tempat wisata yaitu: Grafika Cikole (GC), Orchid Forest (OF), The Lodge Maribaya (TLM), dan Farmhouse (FH). Pada Gambar 6. lintasan awal sudah ditentukan berada di Grafika Cikole (GC).

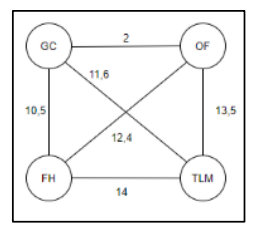

Gambar 6 Simulasi Cara Kerja Steepest Ascent Hill Climbing

Pada Gambar 7. Perhitungan jarak setiap antar kota dengan menggunakan Google Maps.

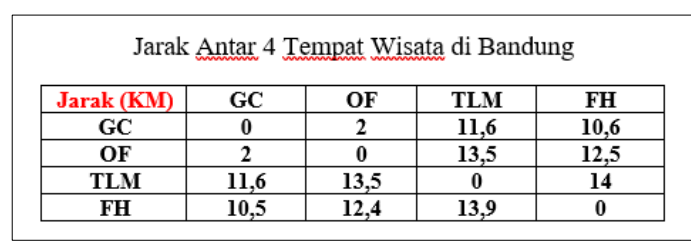

Gambar 7. Pencarian jarak antar tempat wisata menggunakan Google Maps

Terdapat 4 tahapan dalam proses metode steepest ascent hill climbing yaitu:

1. Rumus mencari Steepest Ascent Hill Climbing:

$$
\begin{aligned}
\mathrm{K} & =\frac{n !}{2 !(n-2) !}=\frac{4 !}{2 !(4-2) !}=\frac{4 \cdot 3 \cdot 2 \cdot 1}{2 \cdot 1(2) !}=\frac{4 \cdot 3}{2 \cdot 1}=\frac{12}{2} \\
& =6 \text { Kombinasi }
\end{aligned}
$$

2. Pola kombinasi tukar antar titik tujuan: 
Pada Gambar 17. untuk V yaitu (GC, OF, TLM, $\mathrm{FH})$, dan untuk $\mathrm{E}$ yaitu ((2), (13.5), (14), (12.4), (11.6), (10.5)).

Pola kombinasi tukar tempat wisata:

1. $(1,2)$ : Menukar posisi kota kesatu dengan kota kedua.

2. (1,3): Menukar posisi kota kesatu dengan kota ketiga.

3. $(1,4)$ : Menukar posisi kota kesatu dengan kota keempat.

4. $(2,3)$ : Menukar posisi kota kedua dengan kota ketiga.

5. $(2,4)$ : Menukar posisi kota kedua dengan kota keempat.

6. $(3,4)$ : Menukar posisi kota ketiga dengan kota keempat.

3. Pencarian

Keadaan awal berada di GC, OF, TLM, FH dengan jarak tempat wisata 29,5 KM.

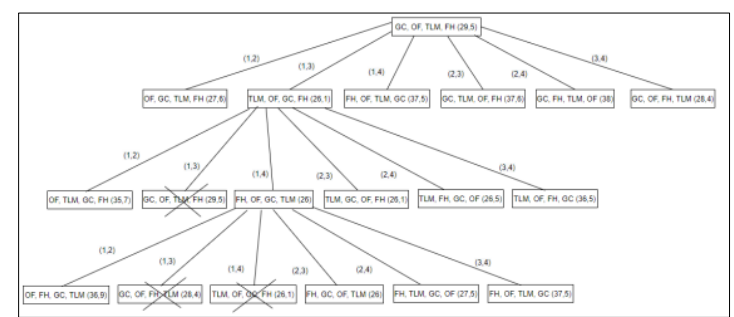

Gambar 8. Hasil pencarian

Berdasarkan Gambar 8, keadaan awal lintasan yaitu (GC - OF - TLM - FH) dengan jarak 29,5 KM.

1. Pada level satu, yang memiliki nilai heuristik yang lebih baik dari lintasan (GC - OF TLM - FH) yang panjangnya 29,5 KM adalah lintasan (TLM - OF - GC - FH) dengan lintasan sama dengan 26,1 KM. Maka dipilihnya node (TLM - OF - GC - FH) untuk pencarian selanjutnya.

2. Pada level dua, dari lintasan (TLM - OF $\mathrm{GC}-\mathrm{FH}$ ) diperoleh lintasan terbaik yaitu (FH - OF - GC - TLM) dengan panjang lintasan sama dengan 26,1 KM dan lebih baik dibandingkan dengan lintasan sebelumnya dan juga node-node tetangganya.

3. Pada level tiga, tidak ditemukan nilai heuristic yang lebih baik dibandingkan lintasan (FH - OF - GC - TLM) sehingga pencarian berhenti dan solusi yang diperoleh untuk lintasan terpendek adalah (FH - OF GC - TLM) dengan panjang lintasan adalah 26 KM.(Pada level tiga, nilainya tidak ada yang lebih kecil dari yang sebelumnya, maka nilai terkecil itu adalah GOAL).

\subsection{Flowchart}

Flowchart terbagi menjadi yaitu flowchart utama dan flowchart sub proses. Flowchart akan merepresentasikan gambaran proses kerja pada Gambar 9., berikut. 


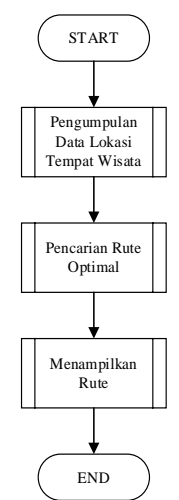

Gambar 9. Flowchart Utama

Berdasarkan Gambar 10., dijelaskan mengenai alur kerja yang akan dilalui pengguna yaitu sebagai berikut:

1. Pengumpulan data lokasi tempat wisata.

2. Pencarian rute optimal.

3. Menampilkan rute optimal dengan menggunakan GPS yang tersedia di perangkat Android.

\section{Flowchart Pengumpulan Data}

Flowchart ini akan menjelaskan alur kerja dari sub-proses flowchart utama yang akan digambarkan oleh Gambar 11.

Berdasarkan Gambar 11., yang telah ditunjukkan dijelaskan mengenai sub proses dari Pengumpulan data lokasi tempat wisata berdasarkan dari flowchart utama yaitu:

1. Menentukan lokasi tempat wisata pada daftar pencarian tempat wisata.

2. Mencari nilai latitude, longitude dan Place ID. Nilai ini dijadikan sebagai pembuatan nilai (evaluasi) pada metode steepest ascent hill climbing.

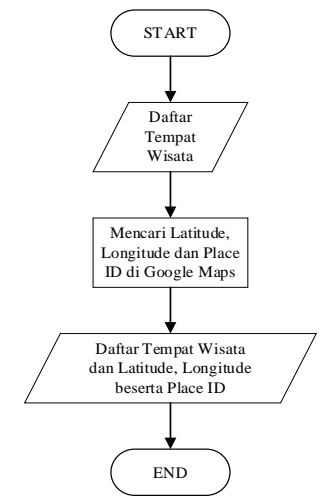

Gambar 10. Flowchart Sub-Proses Pengumpulan

Data

2. Flowchart Sub-Proses Pencarian Jarak Tempat Wisata

Flowchart ini akan menjelaskan alur kerja dari sub-proses Pencarian Rute Optimal dimana fungsinya untuk mencari jarak antar tempat wisata yang akan digambarkan oleh Gambar 13.

Berdasarkan Gambar 13., dijelaskan bahwa tahapan flowchart pencarian jarak tempat wisata yaitu pada daftar place id dimana berisi data latitude dan data longitude, setelah itu place id dijadikan parameter untuk Google Maps untuk mencari jarak antar tempat wisata, setelah di proses maka akan menghasilkan daftar jarak antar tiap tempat wisata.

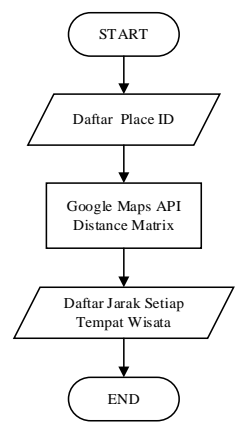

Gambar 11. Flowchart Sub-Proses Pencarian Jarak Tempat Wisata 
3. Flowchart Pencarian Jarak Terpendek Antar Tempat Wisata

Flowchart ini akan menjelaskan alur kerja dari sub-proses Metode Steepest Ascent Hill Climbing, dimana fungsinya untuk pencarian jarak terpendek antar tempat wisata yang akan digambarkan oleh Gambar 17.

Berdasarkan Gambar 17., dijelaskan bahwa subproses Pencarian Jarak Terpendek Antar Tempat Wisata yaitu masukkan berupa initial state dan successor, lalu ada pengecekkan sistem, jika nilai lintasan initial state lebih kecil sama dengan nilai lintasan salah satu successor nya maka lintasan initial state menjadi lintasan terpendek dan proses metode selesai, tetapi jika nilai lintasan salah satu successor nya lebih kecil sama dengan nilai lintasan initial state maka lintasan tersebut menjadi current state. Setelah itu, sitem akan membuat daftar lintasan baru berdasarkan teori graph berjumlah total kombinasi dan akan dibandingkan kembali dengan current state, proses akan diulang terus menerus hingga niai current state menjadi paling kecil dan proses metode selesai.

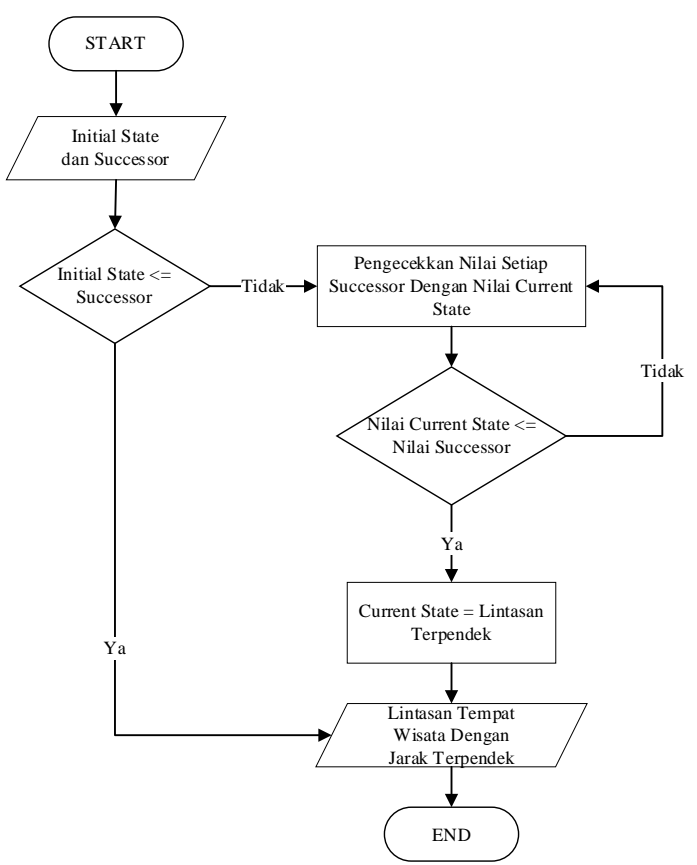

Gambar 12. Flowchart Sub-Proses Pencarian Jarak Terpendek Antar Tempat Wisata

\section{Hasil dan Pembahasan}

Pada bagian ini akan menjelaskan hasil dan pembahasan dari pengujian yang telah dilakukan secara fungsionalitas. Berikut penjelasannya.

Terdapat 3 tahapan pada pengujian sistem:

1. Menampilkan Marker Lokasi Tempat Wisata Pada bagian ini merupakan pengujian pada perintah yang berfungsi untuk menampilkan 4 tempat wisata sebagai lokasi tujuan.

Tabel 1. Marker Lokasi Tempat Wisata

\begin{tabular}{|c|c|c|}
\hline \multicolumn{3}{|c|}{ Kriteria Evaluasi Uji } \\
\hline \multicolumn{3}{|c|}{$\begin{array}{c}\text { Mengambil data latitude dan longitude lokasi } \\
\text { tempat wisata }\end{array}$} \\
\hline \multicolumn{3}{|c|}{ Kasus dan Hasil Uji } \\
\hline Masukan & Harapan & Kesimpulan \\
\hline $\begin{array}{c}\text { Data latitude } \\
\text { dan longitude } \\
\text { lokasi tempat } \\
\text { wisata. }\end{array}$ & $\begin{array}{l}\text { Aplikasi dapat } \\
\text { menampilkan lokasi } \\
\text { setiap tempat } \\
\text { wisata. }\end{array}$ & $\begin{array}{c}{[\sqrt{ }]} \\
\text { Berhasil }\end{array}$ \\
\hline & Output & \\
\hline
\end{tabular}




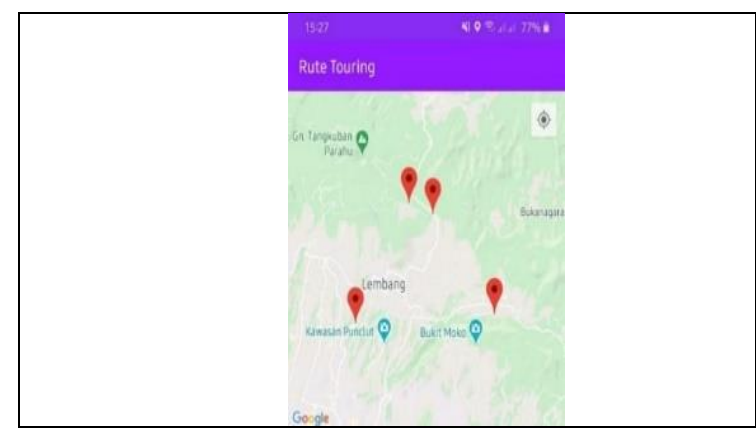

\section{Pengujian Lintasan Awal Tujuan}

Tabel 2. Pengujian Lintasan Awal Tujuan

\section{Kriteria Evaluasi Uji}

Sistem menampilkan 4 tempat wisata dengan menjadikan salah satu tempat wisata sebagai lintasan awal pencarian.

\begin{tabular}{|c|c|c|}
\hline \multicolumn{3}{|c|}{ Kasus dan Hasil Uji } \\
\hline Masukan & Harapan & Kesimpulan \\
\hline Daftar & Aplikasi dapat & {$[\sqrt{ }]$} \\
tempat & menampilkan lokasi & Berhasil \\
wisata yaitu & tempat wisata sesuai & \\
nama dan & dengan lintasan awal & \\
juga alamat & & \\
\hline \multicolumn{3}{|c|}{} \\
\hline
\end{tabular}

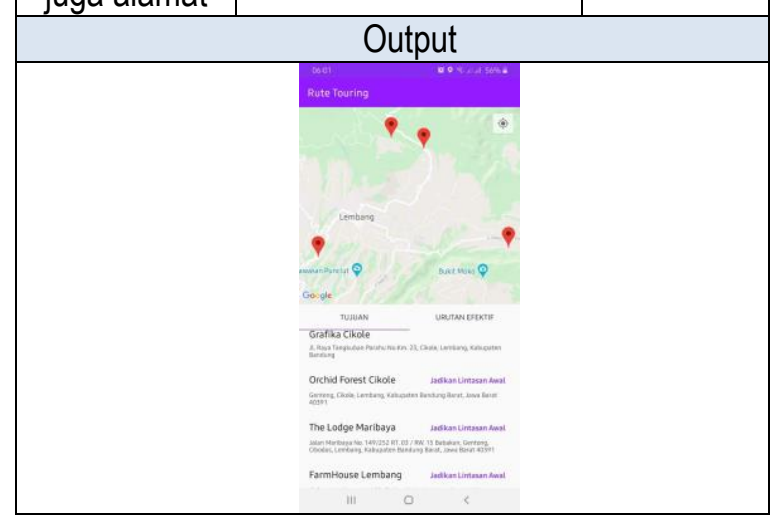

3. Pengujian Metode Steepest Ascent Hill Climbing

Tabel 3. Pengujian Metode Steepest Ascent Hill Climbing

\begin{tabular}{|c|c|c|}
\hline \multicolumn{3}{|c|}{ Kriteria Evaluasi Uji } \\
\hline $\begin{array}{c}\text { Sistem dapat menampilkan daftar rute paling } \\
\text { optimal (tercepat) sesuai dengan metode } \\
\text { steepest ascent hill climbing. }\end{array}$ \\
\hline \multicolumn{3}{|c|}{ Kasus dan Hasil Uji } \\
\hline Masukan & Harapan & Kesimpulan \\
\hline $\begin{array}{c}\text { Titik lintasan } \\
\text { dari daftar } \\
\text { yang sudah }\end{array}$ & $\begin{array}{c}\text { Sistem dapat } \\
\text { menampilkan daftar } \\
\text { rute menuju tempat }\end{array}$ & $\begin{array}{c}{[\sqrt{ }]} \\
\text { Berhasil }\end{array}$ \\
\hline
\end{tabular}

\begin{tabular}{|c|c|c|}
\hline ditentukan & wisata & \\
\hline & Output \\
\hline & & \\
& & \\
& & \\
& & \\
&
\end{tabular}

4. Pengujian Metode Steepest Ascent Hill Climbing

Tabel 4. Pengujian Metode Steepest Ascent Hill Climbing

\begin{tabular}{|c|c|c|}
\hline \multicolumn{3}{|c|}{ Kriteria Evaluasi Uji } \\
\hline \multicolumn{3}{|c|}{$\begin{array}{l}\text { Sistem dapat menampilkan daftar rute paling } \\
\text { optimal (tercepat) sesuai dengan metode steepest } \\
\text { ascent hill climbing. }\end{array}$} \\
\hline \multicolumn{3}{|c|}{ Kasus dan Hasil Uji } \\
\hline Masukan & Harapan & Kesimpulan \\
\hline $\begin{array}{c}\text { Titik lintasan } \\
\text { dari daftar } \\
\text { yang sudah } \\
\text { ditentukan }\end{array}$ & $\begin{array}{c}\text { Sistem dapat } \\
\text { menampilkan daftar } \\
\text { rute menuju tempat } \\
\text { wisata }\end{array}$ & $\begin{array}{c}{[\sqrt{ }]} \\
\text { Berhasil }\end{array}$ \\
\hline \multicolumn{3}{|c|}{ Output } \\
\hline & 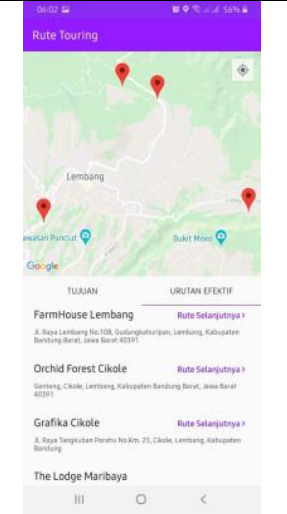 & \\
\hline
\end{tabular}

\section{Kesimpulan}

Berdasarkan pengujian sistem yang dilakukan, metode steepest ascent hill climbing yang 
digunakan sebagai metode utama penelitian ini dapat diimplementasikan pada pencarian rute terefektif atau tercepat dengan menggunakan metode graph tidak berarah untuk proses penukaran antar tempat wisata.

\section{Daftar Pustaka}

[1] N. F. Ariyani, I. Fadhila and A. Munif, "Rekomendasi Rute Kunjungan Tempat Wisata Menggunakan Ontologi dan Algoritma A*," Jurnal Riset dan Konseptual, 2020.

[2] A. B. Prakoso, Y. Ariyanto and A. R. Tri Hayati Ririd, "Optimasi Rute Lokasi Wisata Kota Malang Menggunakan Metode Algoritma Genetika," Jurnal Informatika Polinema, vol. 3, no. 3, pp. 48-52, May 2017.

[3] R. Kurniawati, "Perbandingan Algoritma Dijkstra Dan Algoritma Steepest Ascent Hill Climbing Dalam Menentukan Rute Terpendek (Studi Kasus: Antar Lokasi Objekwisata Di Kabupaten Serdang Bedagai)," 2018.

[4] K. K. Nana, B. Prihandono and E. Noviani, "Penyelesaian Travelling Salesman Problem Menggunakan Metode Simple Hill Climbing," Buletin IImiah Math. Stat. dan Terapannya (Bimaster), 2015.

[5] L. A. Zemma, H. and A. Qur'ania, "Penerapan Metode Steepest Ascent Hill Climbing pada Model pencarian Rute Terdekat Fasilitas Pelayanan Darurat Di Kota Bogor Berbasis Android," e-Journal, pp. 1-11, 2017.

[6] Y. A. Adharani, E. Susilowati and E. Purwanto, Penerapan Metode Simple Hill Climbing Search Untuk Pencarian Lokasi Terdekat Sekolah Menengah Atas Muhammadiyah, 2017.
[7] H. Anam, F. S. Hanafi, A. F. Adifia, A. F. Ababil and S. Bukhori, "Penerapan Metode Steepest Ascent Hill Climb pada Permainan Puzzle," Informatics Journal, vol. 3, no. 2, pp. 36-40, 2018.

[8] E. V. Dangkua, V. Gunawan and K. Adi, "Penerapan Metode Hill Climbing Pada Sistem Informasi Geografis Untuk Mencari Lintasan Terpendek," Sistem Informasi Bisnis, pp. 19-25, March 2015.

[9] E. Darnila, R. and N. , "Aplikasi Pencarian Rute Terdekat Lokasi Klinik Kesehatan Menggunakan Algoritma Steepest Ascent Hill Climbing," Techsi e-Journal, vol. 11, no. 2, pp. 268-279, July 2019.

[10] I. Fadhillah, Y. Permanasari and E. Harahap, "Representasi Matriks untuk Proses Crossover Pada Algoritma Genetika untuk Optimasi Travelling Salesman Problem," Matematika, pp. 1-10, 2017.

[11] V. Y. I. Ilmaru, T. Sumah, Y. A. Lesnussa and Z. A. Leleury, "Perbandingan Algoritma Hill Climbing Dan Algoritma Ant Colony Dalam Penentuan Rute Optimum," Jurnal IImu Matematika dan Terapan, vol. 11, no. 2, pp. 139-150, December 2017.

[12] M. Irfan, "Penyelesaian Travelling Salesman Problem (TSP) Menggunakan Algoritma Hill Climbing dan MATLAB," Matematika, vol. 16, no. 2, pp. 13-20, December 2017.

[13] W. Uriawan, A. Faroqi and R. Fathonah, "Pembuatan Game Slider Puzzle Menggunakan Metode Steepest Ascent Hill Climbing Berbasis Android," ISTEK, vol. 9, no. 1, pp. 204-221, June 2015.

[14] Miftahurrahmah, "Aplikasi Teori Graf Dalam Pengaturan Lampu Lalu Lintas," 2016. 